Wyższa Szkoła Gospodarki Euroregionalne

im. Alcide De Gasperi w Józefowie

KRZYSZTOF PAJĄK

Wojskowa Akademia Techniczna

krzysztofpajak@wp.pl

\title{
ANAlysis of THE POSSIBILITIES OF Poland's PARTICIPATION IN THE UTILIZATION OF HAZARDOUS CHEMICALS BASED ON THE EXPERIENCE OF THE DANISH RECLIB OPERATION
}

\author{
ANAliza MOŻliwości UdZIAŁU POLSKI \\ W UTYLIZACJI NIEBEZPIECZNYCH SUBSTANCJI \\ CHEMICZNYCH W OPARCIU O DOŚWIADCZENIA \\ DUŃSKIEJ OPERACJI PK. RECLIB
}

\begin{abstract}
Analysis of the possibilities of Poland's participation in the utilization of hazardous chemicals based on the experience of the Danish RECLIB operation. The article reviews the implementation of the maritime policy by the Kingdom of Denmark as the examples of an operation, carried out in 2016, under the code name RECLIB, whose the main aim was to remove harmful chemical substances from Libya. The process of setting up maritime operation under the leadership of Denmark was described, while conducting an active international policy, including in the forum of the UN Security Council. The cooperation of Denmark with other countries was also presented, for which counteracting the weapon of mass destruction (WMD) proliferation, especially under the auspices of the United Nations, is a high priority in foreign policy. Finally, Polish extensive experience in the area of chemical weapon utilization was mentioned and an attempt was made to define the national ability to carry out a maritime operation of removing WMD from another country. For this purpose, the authors studied the CBRN capabilities and abilities of the Polish Navy to transport of dangerous substances as part of a potential naval operation.
\end{abstract}




\section{STRESZCZENIE}

Artykuł przedstawia analizę możliwości udziału Polski w utylizacji niebezpiecznych substancji chemicznych w oparciu o doświadczenia duńskiej operacji pod kryptonimem RECLIB. W artykule przedstawiono sposób realizacji przez Królestwo Danii jednego z elementów polityki zagranicznej na przykładzie przeprowadzonej w $2016 \mathrm{r}$. operacji pod kryptonimem RECLIB, której głównym celem było usunięcie z Libii niebezpiecznych substancji chemicznych. Opisany został proces przeprowadzenia morskiej operacji pod przewodnictwem Danii przy jednoczesnym prowadzeniu aktywnej polityki międzynarodowej, w tym na forum Rady Bezpieczeństwa ONZ. Zaprezentowane zostało również współdziałanie Danii z innymi państwami, dla których przeciwdziałanie proliferacji broni masowego rażenia, zwłaszcza pod auspicjami Organizacji Narodów Zjednoczonych, stanowi wysoki priorytet w polityce zagranicznej. Omówione zostały także polskie, szerokie doświadczenia z zakresu utylizacji broni chemicznej i podjęto próbę zdefiniowania krajowych zdolności do usunięcia broni masowego rażenia z innego państwa w ramach operacji morskiej. W tym celu Autorzy przeanalizowali zdolności z zakresu obrony przed bronią masowego rażenia (OPBMR) i możliwości Marynarki Wojennej RP w zakresie transportu substancji niebezpiecznych z wykorzystaniem posiadanych jednostek bojowych.

KeYWORDs: maritime policy of Denmark, operation RECLIB, marine capabilities, $C B R N$ transportation, $C B R N$ reprocessing, CBRN Defence

SŁowA KLUCzowe: polityka morska Danii, zdolności morskie, operacja RECLIB, transport BMR, utylizacja BMR, OPBMR

\section{WPROWADZENIE}

Prowadzenie aktywnej i skutecznej polityki morskiej nie jest domeną tylko największych państw posiadających potężne siły morskie. Wyzwanie polegające na potwierdzeniu tej tezy podjęło latem 2016 r. Królestwo Danii, przeprowadzając operację pod kryptonimem RECLIB.

Historia operacji rozpoczęła się 16 lipca 2016 r., kiedy libijski Rząd Jedności Narodowej zgłosił formalny wniosek do Organizacji ds. Zakazu Broni Chemicznej (Organization for the Prohibition of Chemical Weapons, OPCW) z prośbą o międzynarodowe wsparcie w celu usunięcia $\mathrm{z}$ Libii substancji chemicznych mogących posłużyć do produkcji broni masowego rażenia (BMR). Chociaż broń chemiczna Libii została niszczona pod nadzorem międzynarodowym w 2014 r., to jednak pewna ilość substancji chemicznych, które mogą być wykorzystane do produkcji broni masowego rażenia, pozostała 
w tym kraju. Libia zadeklarowała posiadanie jeszcze 24,7 ton iperytu siarkowego (gazu musztardowego), 1390 ton prekursorów BMR oraz ponadto 3 tys. bomb z BMR. Z uzyskanych informacji wynika, że do 2013 r. zniszczono 54\% środków i 40\% prekursorów służących do wytworzenia broni chemicznej (Król, 2016). W lutym 2014 r. Libia zakończyła proces niszczenia broni chemicznej kategorii $1 \mathrm{w}$ obiekcie w Ruwagha w prowincji Al-Dżufra. Z kolei w 2016 r. udało się Libii przelać broń chemiczną kategorii 2 (prekursory), przechowywaną w 45 niszczejących zbiornikach, do nowych kontenerów spełniających standardy ISO.

Ograniczanie proliferacji broni masowego rażenia stanowi istotny cel polityki zagranicznej dla większości państw Zachodu. W doktrynach i strategiach wielu państw zapobieganie proliferacji broni masowego rażenia zajmuje priorytetowe miejsce. Stąd też wynika ich duże zaangażowanie w działalność organizacji międzynarodowych, takich jak Grupa Australijska, powołana w 1985 r. po użyciu broni chemicznej przez Irak, czy choćby wspomniane OPCW. Skala zagrożenia BMR i skutki jej użycia sprawiają, że mocarstwa kładą duży nacisk na przestrzeganie traktatu o zakazie broni chemicznej. Należy w tym miejscu przypomnieć, że międzynarodowe negocjacje w tej sprawie rozpoczęły się w ramach Konferencji Rozbrojeniowej ONZ w 1980 r. W dniu 30 listopada 1992 r. Zgromadzenie Ogólne ONZ przyjęło Konwencję o zakazie broni chemicznej w drodze rezolucji A/REs/471391. Uchwalony tekst konwencji przedstawiono do podpisu na początku 1993 r. w Paryżu, a w kwietniu 1997 r., gdy 65. państwo ratyfikowało Konwencję o zakazie prowadzenia badań, produkcji, składowania i użycia broni chemiczną oraz o zniszczeniu jej zapasów, weszła ona w życie, a jej skrócona nazwa to: Konwencja o zakazie broni chemicznej (CWC - Chemical Weapon Convention) (Binek, 2014).

W celu zapobieżenia dostania się libijskich środków chemicznych w ręce terrorystów lub inne niepowołane osoby Rada Wykonawcza OPCW 20 lipca 2016 r. podjęła decyzję wzywającą państwa członkowskie do udzielenia niezbędnej międzynarodowej pomocy libijskiemu Rządowi Jedności Narodowej w zniszczeniu substancji chemicznych mogących posłużyć produkcji broni masowego rażenia. Zadeklarowano, że związki te należą do kategorii 2 Konwencji o zakazie broni chemicznej (Konwencja, 1993). Oznacza to, że choć 
może nie służą bezpośrednio do elaborowania pocisków chemicznych, to na ich bazie można wyprodukować broń chemiczną. Dwa dni później, tj. 22 lipca 2016 r., apel OPCW został powtórzony przez Radę Bezpieczeństwa ONZ, która uchwaliła rezolucję nr 2298. Dała ona podstawę prawną dla państw gotowych do udzielenia pomocy rządowi libijskiemu w zakresie usunięcia broni chemicznej w możliwie najkrótszym czasie (Rezolucja RB ONZ nr 2298). Rezolucja autoryzowała jednocześnie transport, transfer i zniszczenie broni chemicznej przez państwa, które podejmą się tego działania.

Dania, posiadając szerokie doświadczenia w dziedzinie usuwania syryjskiej broni chemicznej, w 2013 i 2014 r. podjęła się analizy możliwości wykonania postanowień rezolucji ONZ. Rząd duński zaproponował 15 sierpnia 2016 r. skierowanie okrętu i promu (ro-ro) do wykonania tego zadania. Wybór padł na okręt desantowy dok HDMS Absalon. Choć jest to okręt klasyfikowany jako LPD (ang. Landing Platform Dock), z powodzeniem realizuje funkcje okrętu desantowego oraz jednostki przeznaczonej do strategicznego transportu morskiego (Bursztyński, 2011), jak również zadania wsparcia dowodzenia. To nowoczesna, zbudowana w 2004 r., wielofunkcyjna jednostka posiadająca pokład startowy o powierzchni $850 \mathrm{~m}^{2}$ i hangar mieszczący dwa śmigłowce. Na jej wyposażeniu znajdują się dwie szybkie łodzie motorowe zdolne przewozić do 9 osób (lub $1800 \mathrm{~kg}$ ładunku). Załogę okrętu tworzy 75 marynarzy, ale można zaokrętować dodatkowych 200. Okręt ma wyporność ok. 6300 ton i osiąga prędkość 24 węzłów.

Biorący udział w operacji RECLIB HDMS Absalon opuścił macierzysty port, udając się w kierunku Libii już 17 sierpnia 2016 r., tj. przed formalną decyzją parlamentu. Na Morzu Śródziemnym dołączył do niego statek ro-ro Ark Futura. Formalna decyzja parlamentu duńskiego o udziale sił zbrojnych Danii w międzynarodowej operacji morskiej, której celem było przetransportowanie broni chemicznej z Libii do Niemiec, zapadła dopiero 19 sierpnia 2016 r. Oznacza to, że przygotowania do operacji musiały się zacząć na kilka tygodni przed oficjalną zgodą na operację. Świadczy to o dużej autonomiczności rządu w prowadzeniu polityki zagranicznej, w tym polityki morskiej. W tym czasie OPCW opracowała plan utylizacji broni chemicznej w ciągu 15 miesięcy od dostarczenia jej do portu w Niemczech. Dania została państwem wiodącym operacji, której nadano kryptonim RECLIB. Poza wy- 
dzieloną fregatą HDMS Absalon i statkiem ro-ro Ark Futura siły zbrojne Królestwa Danii zapewniły dowództwo operacji oraz personel cywilny z duńskiej administracji celnej i podatkowej oraz z duńskiej agencji zarządzania kryzysowego. W operacji udział wzięła również Wielka Brytania, wydzielając jednostkę wsparcia RFA (ang. Royal Fleet Auxiliary) Mounts Bay oraz Finlandia. delegując dwóch specjalistów obrony przed bronią masowego rażenia (OPBMR). Wsparcia finansowego operacji udzieliły Finlandia (500 tys. euro), Wielka Brytania (ok. 500 tys. funtów), Niemcy i Stany Zjednoczone. Wielka Brytania pomogła również w analizie pobranych próbek substancji chemicznych z Libii, którą przeprowadzono w Defence Science and Technology Laboratory w Porton Down.

\section{Zdjęcie 1.}

Zespół okrętów biorących udział w operacji RECLIB (w drodze powrotnej do Europy)

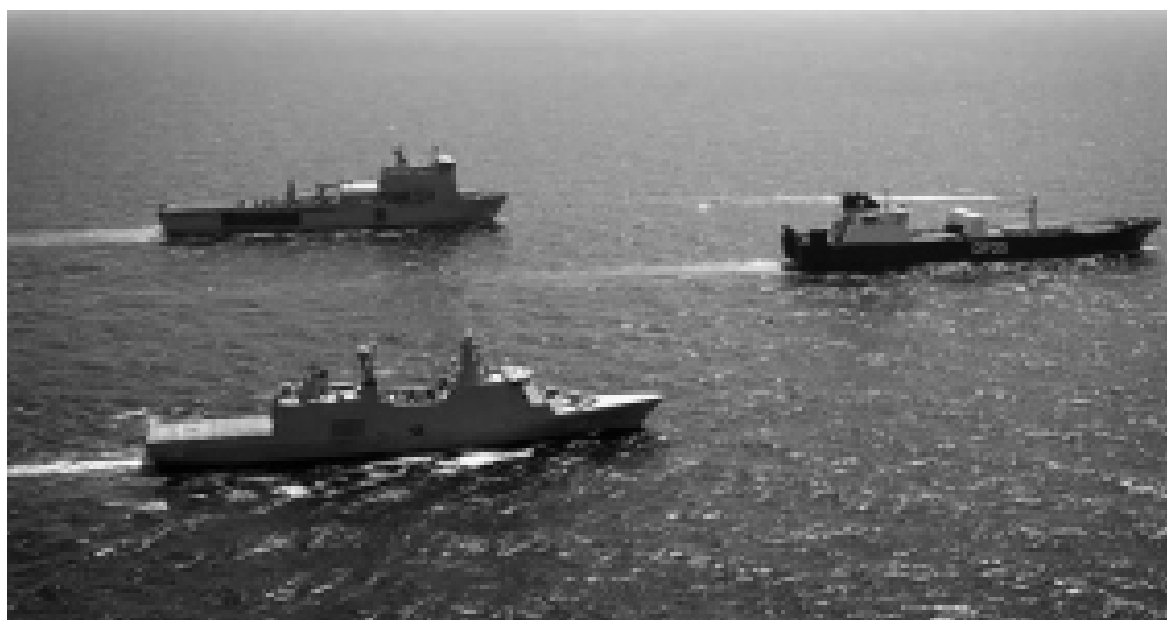

Źródło: http://www.co-sea.dk/nyheder_fra_co_sea/co-soefart.44017/ros-fra-usa-til-danmarkog-herunder-dfds-besaetning.69390 (dostęp: 29.01.2018).

\section{Przebieg operacji RECLIB}

Zespół okrętów biorących udział w operacji RECLIB wszedł na wody terytorialne Libii 27 sierpnia 2016 r. o godz. 5.00, po czym obrały kurs na port w Misracie. Do libijskiego portu wszedł prom Ark Futura i już o godz. 9.00 był gotowy do załadunku substancji chemicznych zgromadzonych przez rząd 
libijski w 23 zbiornikach kontenerowych i jednym kontenerze na portowym nabrzeżu. Przed zaokrętowaniem każdy ładunek był sprawdzany pod względem szczelności. Przygotowane przez libijski rząd ciężarówki poprzez furtę rufową wwoziły kolejne zbiorniki na pokład Ark Futury. Były one ustawiane na pokładzie głównym za pomocą dźwigu i bramownicy. Załadunek został zakończony po 9 godzinach intensywnych prac, po czym prom niezwłocznie wyszedł w morze. Tego samego dnia o godz. 20.00 zespół okrętów opuścił wody terytorialne Libii.

Zdjęcie 2.

Załadunek zbiorników kontenerowych na pokład promu Ark Futura w porcie w Misracie

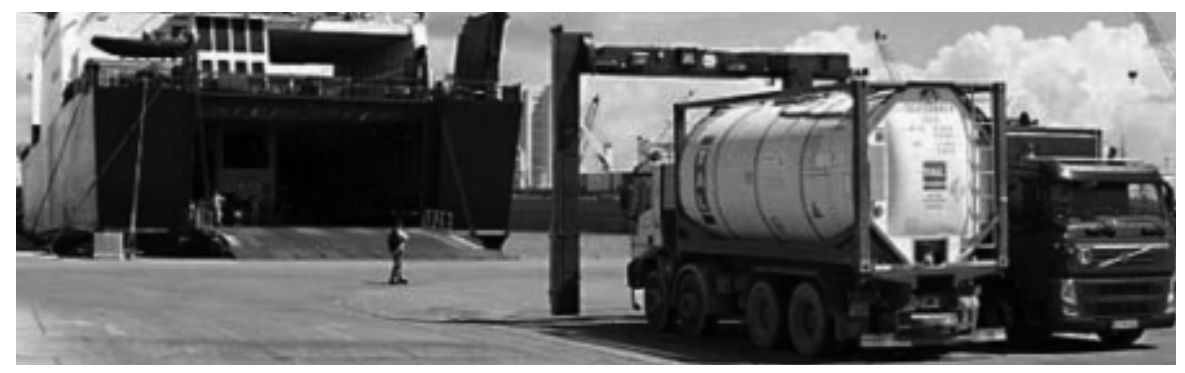

Źródło: http://casr.ca/doc-news-denmark-libya-chemical-weapons-2.htm (dostęp: 29.01.2018).

Rejs na Morze Północne przebiegł bez incydentów, a ładunek był systematycznie sprawdzany przez specjalistów OPBMR. Zespół okrętów dotarł do portu w Bremie już 6 września 2016 r. Wyładunek zbiorników zawierających ok. 500 ton substancji chemicznych nastąpił 8 września 2016 r. Po dotarciu kontenerów na ląd zostały one poddane sprawdzeniu, a ich zawartość została spisana, a następnie były nieprzerwanie monitorowane. Zadanie to wykonywali żołnierze z Centrum Zadań Weryfikacyjnych Bundeswery (Zentrum für Verifikationsaufgaben der Bundeswehr - ZVBw), a dodatkowo towarzyszyli im inspektorzy OPCW. Akredytowane przez OPCW laboratorium Instytutu Technologii OPBMR Bundeswery w Bonn (Wehrwissenschaftliche Institut für Schutztechnologien - ABC-Schutz (WIS) przeprowadziło analizę pobranych próbek chemicznych. Kontenery przekazano do specjalistycznej firmy GEKA w miejscowości Munster (OPCW, 2017) celem 
utylizacji ich zawartości. GEKA, czyli Towarzystwo Likwidacji Chemicznych Środków Bojowych w Munster w Dolnej Saksonii, należy do rządu niemieckiego i nadzorowane jest przez Ministerstwo Obrony Republiki Federalnej Niemiec. W proces niszczenia substancji chemicznych zaangażowanych jest 135 pracowników tego specjalistycznego przedsiębiorstwa. Firma GEKA jest jedynym podmiotem zewnętrznym zajmującym się niszczeniem substancji chemicznych przywiezionych z Libii. Choć OPCW nie było w stanie podać kosztów ich utylizacji, wskazując, że będą dopiero znane po ich całkowitej likwidacji, to jednak Ministerstwo Obrony Republiki Federalnej Niemiec szacuje je na 1,65 mln euro.

Tak skuteczne przeprowadzenie niełatwej operacji wymagało zgrania wielu podmiotów: rządu, dyplomacji i sił zbrojnych. Przede wszystkim należy jednak podkreślić, że włodarze duńscy doskonale rozumieją znaczenie polityki morskiej. Wiedzą, że sprawne wykorzystanie sił morskich wiąże się z niedużymi kosztami, a może się przełożyć na znaczne wpływy międzynarodowe.

\section{MOBILNY SYSTEM UTYLIZACJI BRONI CHEMICZNEJ}

Często do takiego typu operacji włączają się inne państwa wysoko uprzemysłowione i tak właśnie było podczas likwidacji arsenału broni chemicznej pochodzącej z Syrii. Na prośbę Organizacji ds. Likwidacji Broni Chemicznej (OPCW) w drugiej połowie 2014 r., po zidentyfikowaniu i zabezpieczeniu broni chemicznej, wspólnota międzynarodowa ustaliła sposób utylizacji 21 ton syryjskiego iperytu siarkowego. W ten proces zaangażowały się oprócz Niemiec, Danii, Finlandii i Wielkiej Brytanii, także Stany Zjednoczone i Norwegia. USA udostępniły jednostkę pływającą Cape Ray, na której odbywał się transport i utylizacja syryjskiej broni chemicznej. Podczas transportu iperytu przez Morze Śródziemne prowadzono proces neutralizacji polegający na poddaniu 21 ton gazu musztardowego działaniu gorącej wody i wodorotlenku sodu pod wysokim ciśnieniem. W wyniku tej reakcji uzyskano 370 ton hydrolizatu, na który składały się: woda (72\%), wodorotlenek sodu (10\%), thiodiglikol (8\%) i zawierała niewielkie ilości 1,4-dithiane i 1,4-dioxane. Hydrolizat pomimo neutralizacji nadal był niebezpieczny, ponieważ mógłby zostać poddany procesowi chemicznemu i uzyskano by z niego ponownie 
iperyt siarkowy, z tego względu został poddany niszczeniu w wysokiej temperaturze w firmie GEKA, w Niemczech (Drechsel, 2014).

Stany Zjednoczone, zaniepokojone wydarzeniami związanymi z użyciem BMR w Syrii, a zwłaszcza atakiem chemicznym pod Damaszkiem (21.08.2013) oraz z obawy przed przedostaniem się broni chemicznej w niepowołane ręce, zleciły Agencji Redukcji Zagrożeń Obronnych opracowanie projektu mobilnego urządzenia, zdolnego niszczyć składniki broni chemicznej w dowolnym miejscu na świecie. W efekcie tych prac stworzono FDHS (ang. Field Deployable Hydrolysis System), czyli mobilny system hydrolizy polowej. Projekt ten opracowało US Army Edgewood Chemical Biological Center (ECBC) w stanie Meryland (CBARR, 2013).

FDHS umożliwia utylizację powszechnie w przeszłości produkowanej broni chemicznej, m.in. iperytu siarkowego czy sarinu. Zasada jego działania polega na wprowadzeniu związku chemicznego do tytanowego zbiornika o pojemności $8330 \mathrm{dm}^{3}$, a następnie zmieszaniu go z gorącą wodą, wodorotlenkiem sodu i utleniaczem (podchlorynem sodu). Jak deklaruje producent, skuteczność zestawu sięga 99,9\% i jest on w stanie zutylizować do $25 \mathrm{~m}^{3}$ niebezpiecznych związków chemicznych w ciągu doby. Zastosowana metoda początkowo wykorzystywana była do niszczenia amerykańskich zapasów broni chemicznej, zgodnie z wymogami konwencji z 1993 r., jednak stosowano ją tylko w warunkach stacjonarnych (Król, 2016).

System FDHS zapakowany jest do kilku kontenerów i może zostać uruchomiony w ciągu 10 dni, w każdym miejscu na Ziemi. Niestety system posiada również wady, z których najważniejszą jest powstawanie podczas procesu dużej ilości ścieków, których objętość jest 14-krotnie większa od objętości wprowadzonych związków chemicznych. Ścieki te można poddać zwykłej utylizacji, co jest mimo wszystko zaletą tej technologii (Pacholski, 2014).

Zestaw FDHS wyposażony jest w różne systemy zwiększające bezpieczeństwo pracy. Zainstalowano tam m.in. dodatkowe generatory prądu, systemy wentylacyjne, uniemożliwiające wydostanie się nieoczyszczonego powietrza do atmosfery czy sprzęt do likwidacji skażeń personelu. System wyposażony jest w nowoczesne laboratorium $z$ licznym sprzętem analitycznym, takim jak chromatografy gazowe i spektrometry masowe. Pozwala to w sposób dokładny określić związki poddane procesowi utylizacji, a także potwierdzić jej skuteczność i wypełnić wymogi bezpieczeństwa (CBARR, 2013). 
Zdjęcie 3.

System FDHS

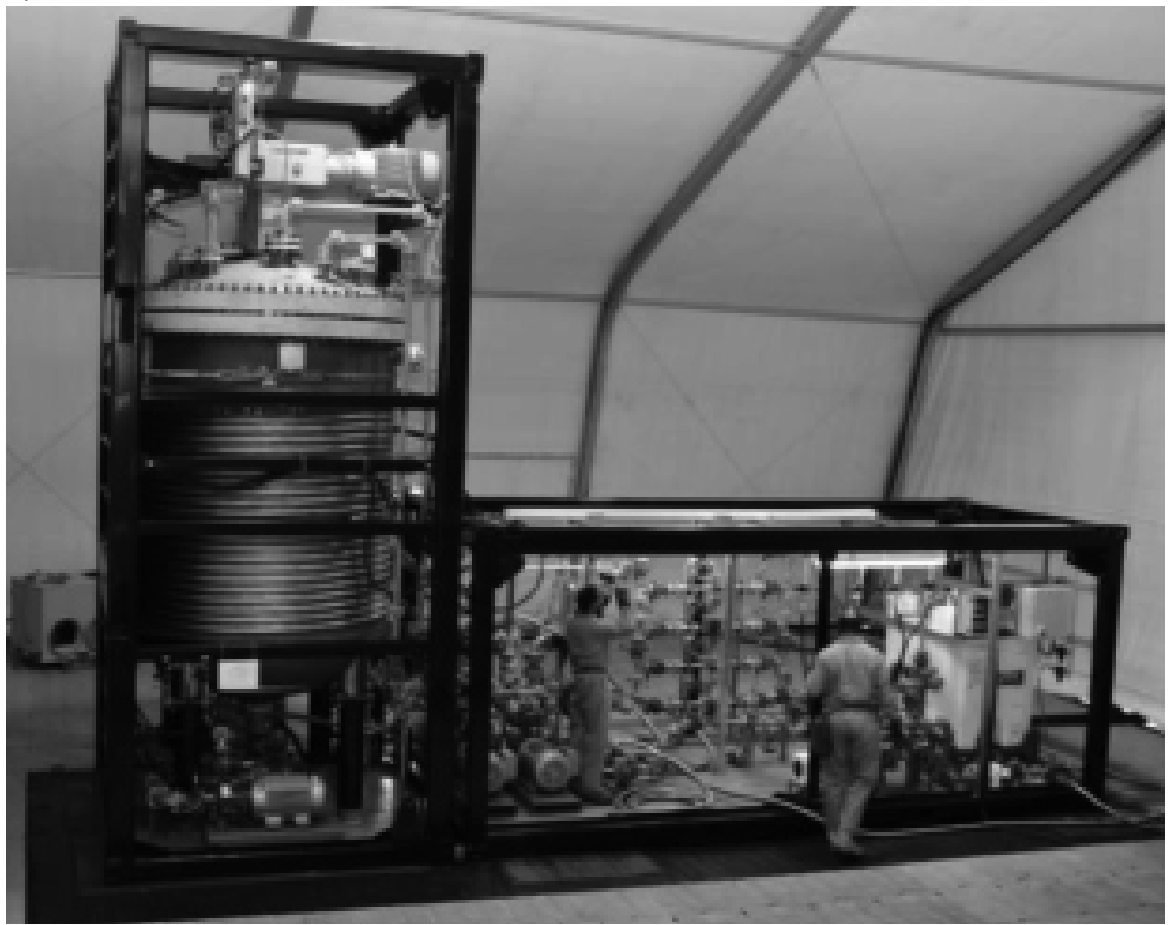

Źródło: https://www.ecbc.army.mil/cbarr/newsletter/2013/CBARR_August2013.pdf(dostęp: 29.01.2018).

\section{Doświadczenia Polski zWiĄzAne Z UTylizacjĄ MATERIAŁÓW NIEBEZPIECZNYCH}

Polska posiada szeroki wachlarz doświadczeń związanych z utylizacją BMR i substancji chemicznych służących do jej produkcji. Niemal każdego roku na terenie Polski odnajdowana jest broń chemiczna. Znaczna część znalezisk to pozostałości przetaczających się przez obecny teren Rzeczpospolitej frontów I i II wojny światowej (Binek, 2013). Znajdowane są także zakopane w glebie substancje chemiczne pochodzące z czasów zimnej wojny, kiedy nie obowiązywała Konwencja o zakazie broni chemicznej, a armie przygotowywały się do wojny totalnej. Od zawsze, zgodnie z polityką militarną, Polska chroniła się przed tego typu związkami (stąd obrona przed bronią masowego 
rażenia OPBMR), a nie zajmowała się produkcją i elaborowaniem pocisków stosowanych w celach ofensywnych (Binek, 2016).

Na przełomie lat 2009-2017 znaleziono na terenie Polski znaczne ilości materiałów niebezpiecznych pochodzenia wojskowego, które stanowiły realne zagrożenie dla ludności cywilnej. Duża liczba znalezisk w tym okresie wynika z rozwoju gospodarczego Polski i związana jest ze zintensyfikowaniem rozbudowy wielu aglomeracji, rozwojem budownictwa mieszkaniowego na byłych terenach wojskowych, a także pozyskanymi środkami z UE na oczyszczanie terenów byłych poligonów wojskowych i terenów lasów państwowych (np. Świętoszów, Borne Sulinowo). Ciekawym znaleziskiem okazało się odkopanie w Warszawie (fort Chrzanów-Bemowo) 352 butli ciśnieniowych pochodzących z I wojny światowej przeznaczonych do uwalniania gazów bojowych. Z badań archeologicznych wynikało, że są one pochodzenia rosyjskiego, gdyż na początku XX w. teren ten zajmował rosyjski pułk piechoty. Najbardziej niebezpiecznym znaleziskiem była odkopana w 2009 r. przez zbieraczy złomu beczka o pojemności $365 \mathrm{dm}^{3}$ zawierająca iperyt siarkowy. Osoby, które znalazły beczkę, wcześniej pozbyły się jej zawartości, jednocześnie ulegając poparzeniu. Skażona ziemia została zebrana przez wyspecjalizowane jednostki Sił Zbrojnych RP, a teren odkażony. W pozostałych znaleziskach, m.in. na terenach kompleksów leśnych Nadleśnictwa Świętoszów i Bornego Sulinowa, odkopano beczki o różnej pojemności zawierające mieszaniny broni chemicznej i jej prekursorów w rozpuszczalnikach, służące do pozorowania skażeń (podczas szkolenia żołnierzy ZSRR stacjonującym na terenie Polski w XX w.). Chloropikrynę, będącą w wykazie 3 Konwencji o zakazie broni chemicznej znajdowano na terenach Jednostek Wojskowych w Żarach, Kłodzku oraz na terenie Centralnej Składnicy Uzbrojenia w Starej Wsi koło Celestynowa. Po oczyszczaniu starych poligonów lotniczych znajdowano również ampułki z kwasem chlorosulfonowym, wykorzystywanym do wskazywania efektywności nalotów bombowych. Kwas chlorosulfonowy jest substancją, która w stanie wolnym i kontakcie z powietrzem dymi i tę właśnie cechę wykorzystywano jako indykator. Ampułki z tym związkiem umieszczane były w treningowych betonowych bombach lotniczych. Substancja, która służyła Niemcom do zadymiania podczas II wojny światowej, znajdowana była również w beczkach 200-litrowych. 
Tabela 1.

Zestawienie znalezisk $\mathrm{z}$ materiałami niebezpiecznymi na terenie Polski wraz z kosztami ich utylizacji w latach 2009-2017

\begin{tabular}{|c|c|c|c|c|}
\hline Rok & Miejsce & Ilość środków niebezpiecznych & $\begin{array}{c}\text { Koszt } \\
\text { utylizacji } \\
{[\mathrm{z}]}\end{array}$ & Uwagi \\
\hline \multirow{2}{*}{2009} & \multirow{2}{*}{$\begin{array}{l}\text { Borne } \\
\text { Sulinowo }\end{array}$} & $365 \mathrm{dm}^{3}$ beczka $\mathrm{z}$ iperytem & $\begin{array}{l}\text { Brak } \\
\text { danych }\end{array}$ & $\begin{array}{l}\text { Utylizacji podjął } \\
\text { się WICHIR }\end{array}$ \\
\hline & & 171 kg odpadów & \multirow{4}{*}{35000} & \\
\hline 2013 & Żary & 7 ampułek chloropikryny & & \\
\hline \multirow[b]{2}{*}{2014} & Kłodzko & 1 ampułka chloropikryny & & \\
\hline & $\begin{array}{l}\text { Lidzbark } \\
\text { Warmiński }\end{array}$ & $\begin{array}{c}1 \text { butla ciśnieniowa z substancjami } \\
\text { niebezpiecznymi }\end{array}$ & & \\
\hline \multirow{3}{*}{2015} & Świętoszów & $\begin{array}{l}19 \text { beczek o poj. } 360 \mathrm{dm}^{3} \\
6 \text { pojemników o poj. } 70 \mathrm{dm}^{3} \\
1 \text { pojemnik o poj. } 115 \mathrm{dm}^{3}\end{array}$ & \multirow[t]{2}{*}{430000} & \\
\hline & $\begin{array}{l}\text { Borne } \\
\text { Sulinowo }\end{array}$ & 18 beczek o poj. $360 \mathrm{dm}^{3}$ & & \\
\hline & $\begin{array}{l}\text { Bemowo fort } \\
\text { Chrzanów }\end{array}$ & $\begin{array}{l}17 \text { pełnych butli ciśnieniowych } \\
(88 \times 22)-\text { waga } 23 \mathrm{~kg} \\
335 \text { uszkodzonych butli } \\
\text { ciśnieniowych }\end{array}$ & 20000 & $\begin{array}{c}\text { Koszt dotyczył } \\
\text { badania i utylizacji } \\
\text { zawartości } 3 \text { butli } \\
\text { ciśnieniowych }\end{array}$ \\
\hline \multirow{3}{*}{2016} & $\begin{array}{l}\text { Krosno } \\
\text { Odrzańskie }\end{array}$ & $\begin{array}{l}2 \text { pojemniki z niebezpieczną } \\
\text { substancją }(50 \times 20 \mathrm{~cm})\end{array}$ & \multirow[b]{2}{*}{5000} & \\
\hline & \multirow[t]{2}{*}{ Latkowo } & $\begin{array}{c}31 \text { fiolek z kwasem } \\
\text { chlorosulfonowym } \\
61 \mathrm{~kg} \text { uszkodzonych fiolek } \\
\text { z sorbentem }\end{array}$ & & \\
\hline & & 4 fiolki z kw. chlorosulfonowym & \multirow{5}{*}{$\begin{array}{l}\text { Brak } \\
\text { danych }\end{array}$} & \multirow{5}{*}{ Nie zutylizowano } \\
\hline \multirow{3}{*}{2017} & Celestynów & 26 pojemników z chloropikryną & & \\
\hline & Lębork & 3 ampułki $z$ kw. chlorosulfonowym & & \\
\hline & Elbląg & $\begin{array}{l}132 \text { imitatory skażeń IS-2 } \\
\text { (iperytu siarkowego) }\end{array}$ & & \\
\hline 2018 & $\begin{array}{c}\text { Stargard } \\
\text { Szczeciński }\end{array}$ & $\begin{array}{l}2 \text { beczki o pojemności } 200 \mathrm{dm}^{3} \\
\text { z kwasem chlorosulfonowym }\end{array}$ & & \\
\hline
\end{tabular}

Źródło: opracowanie własne na podstawie danych ze Składu Materiałowego 2 RBlog. 
Usunięciem znalezisk niebezpiecznych substancji chemicznych $\mathrm{z}$ terenu Polski, jeśli są pochodzenia wojskowego, zajmuje się specjalnie do tego powołana wojskowa grupa zadaniowa, w skład której wchodzą wojskowi specjaliści z różnych dziedzin, m.in. chemicy, saperzy, medycy. Zaangażowanie sił zbrojnych w ten rodzaj reagowania kryzysowego następuje każdorazowo po złożeniu wniosku terytorialnie właściwego wojewody do Ministra Obrony Narodowej, który wydaje decyzję o użyciu pododdziałów wojskowych.

Zaangażowani w reagowanie kryzysowe chemicy i saperzy usuwają niebezpieczne znaleziska, a następnie pakują substancje chemiczne w taki sposób, by nie zagrażały ludziom i środowisku. Zanim zostaną zutylizowane przez wyspecjalizowane firmy cywilne, są przechowywane w Składzie Materiałowym 2 Regionalnej Bazy Logistycznej (2RBlog). Samą utylizacją znalezionych związków chemicznych na terenie Polski zajmują się wyspecjalizowane przedsiębiorstwa, m.in. Grupa Azoty czy Raf-Ekologia Sp. z o.o. Koszt zneutralizowania niebezpiecznych substancji uzależniony jest od zastosowanego procesu. Do tej pory za utylizację znalezisk z lat 2009-2016 Skarb Państwa zapłacił ok. 500 tys. zł, a wybór firmy odbywał się na zasadach określonych w Prawie zamówień publicznych.

\section{ANALIZA POLSKICH MOŻLIWOŚCI UTYLIZACJI BRONI MASOWEGO RAŻENIA W RAMACH OPERACJI MORSKIEJ}

Analizując morską operację RECLIB, należy uznać ją za niewątpliwy sukces międzynarodowy Danii, która kolejny raz przyczyniła się do poprawy bezpieczeństwa światowego, pomagając zlikwidować potencjalne zagrożenie, jakie mogłoby wynikać z użycia broni masowego rażenia. Choć jest to nieduże państwo, ponownie pokazało, jak doskonale potrafi prowadzić politykę międzynarodową. Jej dyplomaci bezbłędnie poruszają się w meandrach organizacji międzynarodowych oraz sprawnie korzystają z przyjacielskich relacji z najbliższymi partnerami. Nade wszystko Dania udowodniła, że posiada sprawną flotę, która jest gotowa wykonać nawet bardzo skomplikowane zadania niemal na zawołanie.

W tym miejscu zasadne wydaje się pytanie: czy Polska byłaby w stanie przeprowadzić podobną operację? Odpowiedź na nie leży w określeniu pewnego rodzaju potencjału kraju. Poza sprawną dyplomacją i decyzyjnością polityków kluczowe są zdolności z zakresu OPBMR i możliwości Marynarki Wojennej do przeprowadzenia operacji morskiej. 
Rozpatrując pierwszy czynnik, należy zdawać sobie sprawę, że z zakresu OPBMR niezbędne są zdolności do wykrycia i monitorowania skażenia oraz potencjalnych wycieków w czasie przewozu substancji chemicznych do Europy. Nieodzowna jest również zdolność do likwidacji skażenia w przypadku wystąpienia rozszczelnienia zbiornika z substancjami chemicznymi. Polska, dysponując licznymi jednostkami wojskowymi z wysoko rozwiniętymi zdolnościami z zakresu OPBMR, z pewnością byłaby w stanie wydelegować kilku specjalistów wraz ze specjalistycznym sprzętem. Umiejętności i kompetencje polskich żołnierzy z korpusu osobowego OPBMR były wielokrotnie sprawdzane i potwierdzane podczas licznych międzynarodowych ćwiczeń i zobowiązań sojuszniczych.

Z kolei co do możliwości utylizacji tych związków na terenie Polski, to przedsiębiorstwa zawodowo zajmujące się utylizacją przemysłową substancji niebezpiecznych nie są przygotowane do niszczenia BMR lub ich prekursorów. Można jednak pokusić się o wstępną analizę kosztów i problemów, jakie należałoby rozwiązać, by do takiej utylizacji mogło na terenie Polski dojść. Rozszerzenie działalności wiązałoby się z koniecznością zdobycia pozwoleń, a co za tym idzie, m.in. sprawdzeniem instalacji pod względem oddziaływania na środowisko, uzyskaniem pozytywnych opinii instytucji państwowych, takich jak: Państwowa Inspekcja Pracy, Państwowa Stacja Sanitarno-Epidemiologiczna czy Państwowa Straż Pożarna. Wszystkie wnioski w tej sprawie opiniowane są przez urzędy gmin, na terenie których spalarnie prowadzą działalność, co pewnie spotkałoby się z nieprzychylną opinią mieszkańców, w związku z powszechnie panującym strachem przed BMR.

Gdyby z kolei te związki miały zostać dostarczone z zagranicy (tak jak w omawianym przypadku), wymagane jest zezwolenie na transgraniczny transport odpadów wydane przez Państwowy Inspektorat Ochrony Środowiska. Kolejnym problemem, w tym przypadku technicznym, jest konieczność dostarczania BMR (lub jej prekursorów) w sposób hermetyczny do komory spalania, wiąże się to z przepakowaniem substancji umieszczonych w kontenerach do szczelnych pojemników o pojemności $10-20 \mathrm{dm}^{3}$ (pojemność uzależniona jest od budowy związku chemicznego), co generuje spore koszty. Kolejne wydatki to zabezpieczenie medyczne procesu spalania, zakup środków ochrony osobistej dla pracowników, magazynowanie odpadu czy 
amortyzacja instalacji. Szacunkowy koszt utylizacji takich związków mógłby wynieść ok. 15 tys. zł/Mg (kalkulacji dokonano, opierając się na danych uzyskanych z firmy RAF Ekologia). Jednak firma RAF Ekologia podkreśla, że ze względu na trudności w unieszkodliwianiu tego typu odpadów (zarówno prawne, jak i organizacyjne oraz eksploatacyjne), nie widzi możliwości przyjęcia i utylizacji odpadów pochodzących z Libii.

Drugą kwestią są zdolności Marynarki Wojennej RP do przeprowadzenia tego typu operacji. W tym miejscu należy zauważyć, że fundamentem operacji RECLIB było skierowanie okrętu HMS Absalon oraz statku ro-ro Ark Futura. HDMS Abslaon zapewniał funkcję okrętu dowodzenia, a prom zdolności transportowe. Dodatkowo operację zabezpieczyła jednostka wsparcia RFA Mounts Bay. Czy polska Marynarka Wojenna posiada zdolności niezbędne do przeprowadzenia podobnej operacji?

\section{Zdjęcie 4.}

Prom Ark Futura (na pierwszym planie) z załadowanymi na pokładzie głównym zbiornikami kontenerowymi oraz okręt HDMS Absalon (z tyłu) w drodze do portu w Bremie

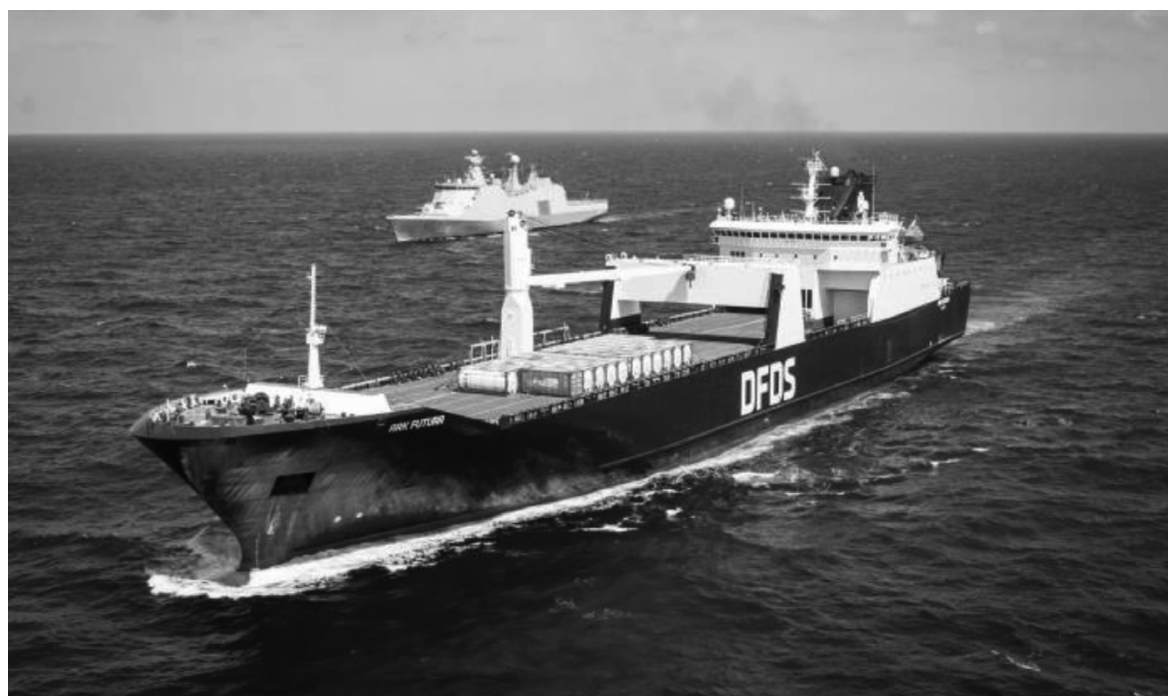

Źródło: http://storbritannien.um.dk/da/News/newsdisplaypage/?newsID=3E217B8E-59D9-40B7-A0D7-7D8767F70A5C dostęp: 29.01.2018). 
Zdjęcie 5.

Brytyjski jednostka wsparcia RFA Mounts Bay podczas realizacji operacji RECLIB

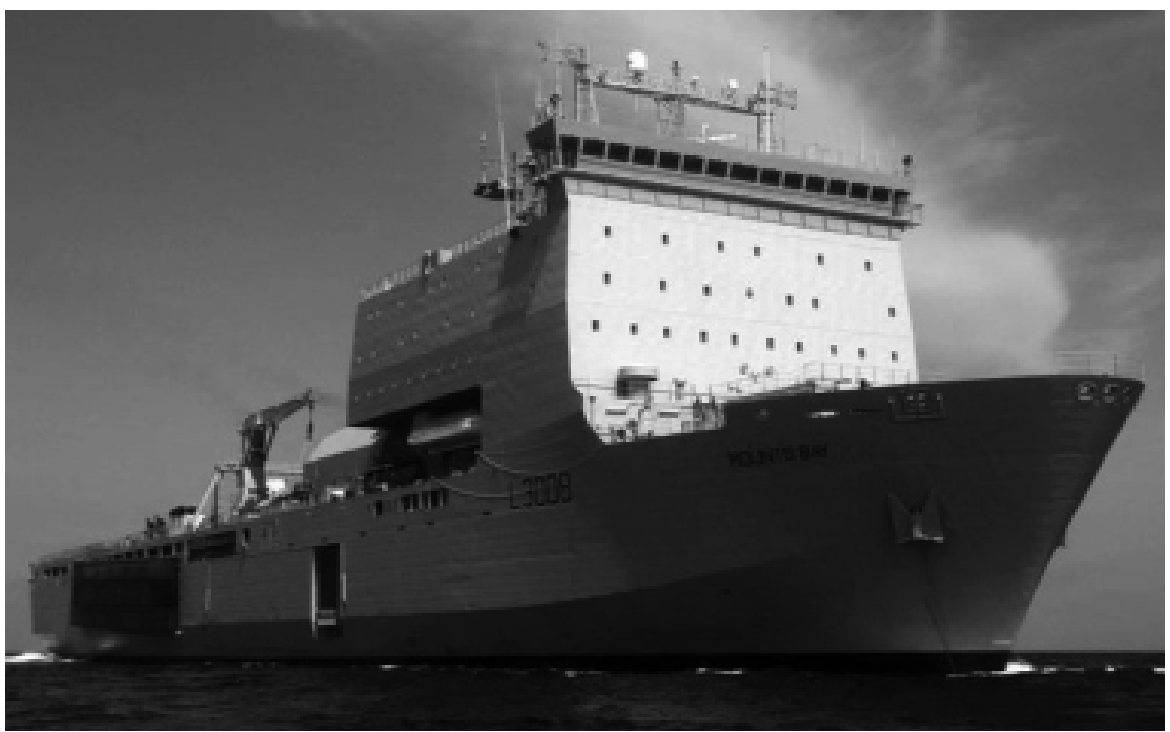

Źródło: http://www.royalnavy.mod.uk/news-and-latest-activity/news/2016/august/31/160831rfa-mounts-bay-supports-removal-of-potential-chemical-weapon-materials-from-libya (dostęp: 29.01.2018).

Do okrętów Marynarki Wojennej RP posiadających zdolności do transportu kontenerów zaliczyć można okręt ORP Xawery Czernicki, który może samodzielnie zaokrętować na pokładzie rufowym 8 kontenerów o masie do 15 ton. Poza ORP Xawery Czernicki kontenery teoretycznie mogłyby być transportowane przez okręty transportowo-desantowe typu Lublin, choć w rzeczywistości nie są przeznaczone do tego zadania. Wymiary ładowni, w teorii, pozwalają zaokrętować 10 kontenerów 20-stopowych. Okręty typu Lublin nie posiadają jednak ani bramownicy, ani żurawi okrętowych umożliwiających samodzielny załadunek. Stanowi to poważne utrudnienie, gdyż zmusza do polegania na infrastrukturze portu (co może być wątpliwe w kraju ogarniętym wojną domową) lub powoduje konieczność transportu dźwigu na podwoziu kołowym albo ciągników kołowych z naczepami. W przypadku klasycznych ciągników z naczepą o długości 13,6 m, zdolnych zabrać 2 kontenery 20-stopowe, okręt pomieściłby 3 takie zestawy, co daje zaledwie 6 kontenerów. 
Zespół okrętów złożonych z ORP Xawery Czernicki i jednego okrętu transportowo-minowego $\mathrm{z}$ pewnością nie byłaby w stanie zabrać całego zapasu zgromadzonych substancji chemicznych w porcie w Misracie (23 kontenery). Niewielkie zanurzenie okrętów typu Lublin sprawia, że wyprawa na Morze Śródziemne przy niesprzyjających warunkach pogodowych mogłaby sprawić specjalistom OPBMR niemałe trudności przy stałym monitoringu szczelności ładunku. Również prędkość wspomnianych okrętów pozostawia wiele do życzenia. Maksymalna prędkość ORP Xawery Czernicki to 13,6 węzła (w), zaś okrętów transporotowo-minowych 16,8 w - to niewiele, jeśli porównamy tę wartość z prędkością maksymalną HDMS Absalon, która wynosi 24 w, 18 w dla RFA Mounts Bay i 17,1 w dla Ark Futura. Zakładając, że zespół polski szedłby z prędkością „cała naprzód”, to i tak poruszałby się średnio o 3,5 węzła wolniej, niż mógłby to robić zespół pod auspicjami Królestwa Danii. Na takiej marszrucie wspomniana różnica prędkości może zwiększyć czas trwania rejsu o ponad 2 dni.

Przedstawione powyżej uwarunkowania sprawiają, że przeprowadzenie operacji podobnej do RECLIB stanowiłoby dla Polski spore wyzwanie, głównie ze względu na ograniczenia, jakie wynikają z wyposażenia i parametrów taktyczno-technicznych okrętów, którymi dysponuje Marynarka Wojenna RP. Zadanie takie jednak mogłoby być wykonane, jeżeli zapewniono by większą liczbę okrętów oraz dodatkowy sprzęt, który musiałby być zaokrętowany i operować w libijskim porcie. Należałoby również rozwiązać problem utylizacji tak dużej ilości prekursorów BMR na terenie Polski. Zauważyć również należy, że polska Marynarka Wojenna posiada dobre doświadczenia w zakresie współpracy i prowadzonych ćwiczeń z marynarką wojenną Królestwa Danii (Pająk, 2010) oraz z flotami większości państw akwenu Morza Bałtyckiego.

\section{ZAKOŃCZENIE}

Polska, chociaż posiada szerokie i unikalne doświadczenia z utylizacji BMR oraz liczne wyspecjalizowane jednostki chemiczne, nie bierze aktywnie udziału w operacjach międzynarodowych tego rodzaju jak operacja RECLIB. Nie angażuje się również w działania mające na celu zapobieganie niekontrolowanemu rozprzestrzenianiu BMR i substancji służących do jej produkcji. $\mathrm{Z}$ pewnością podjęcie takich działań na arenie międzynarodowej dostar- 
czyłoby ważnych argumentów polskim dyplomatom, zwłaszcza w stosunku do kluczowych graczy na obszarze północnoatlantyckim, o których atencję, szczególnie z uwagi na naszą sytuację geostrategiczną, powinniśmy stale zabiegać. Połączenie działań zmierzających do ograniczenia proliferacji BMR z operacją morską wyraźnie kumuluje korzyści. Operacje morskie są bowiem bardzo dobrze postrzegane przez główne kraje członkowskie NATO, w tym Stany Zjednoczone, co pomaga czynić z państwa realizującego takie przedsięwzięcie wiarygodnego sojusznika, angażującego swoje siły w poprawę międzynarodowego środowiska bezpieczeństwa (Pająk, 2011). Jednocześnie ryzyko strat $\mathrm{w}$ ludziach i sprzęcie jest marginalne, a koszty w porównaniu z operacjami lądowymi stosunkowo nieduże. Przedstawione argumenty wymownie wskazują na celowość przeprowadzania tego typu operacji.

Dokonując podsumowania, zauważyć należy, że lepsze zrozumienie przez decydentów prowadzących polską politykę zagraniczną, a także polski korpus dyplomatyczny zdolności, jakie posiadają wojska chemiczne oraz Marynarka Wojenna, stanowi klucz do otworzenia szerokiego wachlarza możliwości politycznych, które mogłyby być z powodzeniem wykorzystane przez nasz kraj na arenie międzynarodowej.

\section{Literatura}

Binek, T., Czepiel, J. (2014). Funkcjonowanie Krajowego Systemu Wykrywania Skażeń i Alarmowania $w$ obecnych uwarunkowaniach systemowych $w$ Polsce, „Safety \& Fire Technique/Bezpieczeństwo i Technika Pożarnicza” Nr 36(4), s. 15-24. ISSN 1895-8443. Binek, T. (2016). Dobre praktyki dowodowego pobierania prób materiałów skażonych substancjami CBRN, „Journal of Modern Science” 1/28, s. 305-324. ISSN 1734- 2031.

Binek, T. (2013). Zagrożenie bronia biologiczna w przeszłości i w obecnym okresie. W: W. Bednarek, A. Ukleja (red.), Wartościowanie bezpieczeństwa w dobie kryzysu, Józefów: Wydawnictwo WSGE. ISBN: 9788362753369.

Bursztyński, A., Kozłowski, D. (2011). Zdolności sił amfibijnych państw Unii Europejskiej. W: „Zeszyty Naukowe Akademii Marynarki Wojennej” Nr 4(1187), s. 141. ISSN 0860-889X.

CBARR NEWS Edgewood Chemical Biological Center, 2013, „The Field Deployable Hydrolysis System” Vol. 1, Issue 8 (dostęp: 6.01.2018).

Konwencja o zakazie prowadzenia badań, produkcji, składowania i użycia broni chemicznej oraz o zniszczeniu jej zapasów, ONZ, Nowy Jork 1993. 
Król, S. (2016). Broń chemiczna $w$ drugiej dekadzie XXI wieku, „Biuletyn Centrum Szkolenia OPBMR Akademii Sztuki Wojennej" Nr 6, R. 4.

OPCW, 2017. Report of the OPCW on The Implementation of the Convention on the prohibition of the development, production, stockpiling and use of Chemical Weapons and on their destruction. C-22/4, In 2016.

Pacholski, Ł. (2014). Historyczna misja MV Cape Ray, „Nowa Technika Wojskowa” Nr 3, s. 96-98. ISSN 1230-1655.

Pająk, K. (2010). Działania polskiej Marynarki Wojennej i Królestwa Danii jako przykład efektywnej kooperacji militarnej w regionie Morza Bałtyckiego w latach 1990-2008. W: M. Bogacki, M. Franz, Z. Pilarczyk (red.), Religia ludów Morza Bałtyckiego, stosunki polsko-duńskie w dziejach, Toruń: Wydawnictwo Adam Marszałek. ISBN 9788376117744.

Pająk, K. (2011). Jak dobrze widać bandere pod wodą? Znaczenie udziału polskich okrętów podwodnych w operacji Active Endavour i ich wplyw na akwenowa politykę bezpieczeństwa na Morzu Śródziemnym. W: A. Kusztelak (red.), Bezpieczeństwo współczesnego świata - wyzwania i zagrożenia, Poznań: Wydawnictwo Wyższej Szkoły Handlu i Usług: Instytut Naukowo-Wydawniczy Maiuscula. ISBN 9788361449287.

Rezolucja Rady Bezpieczeństwa ONZ nr 2298, s. 2.

\section{Źródła internetowe}

Drechsel, A. (2014). Syria's chemical weapons: turning mustard gas into salt in a small Germantown, http://www.dw.com/en/syrias-chemical-weapons-turning-mustardgas-into-salt-in-a-small-german-town/a-17536889 (dostęp: 6.01.2018).

http://www.defence24.pl/12356,okret-wsparcia-orp-kontradmiral-x-czernicki (dostęp: 29.01.2018).

https://www.ecbc.army.mil/cbarr/newsletter/2013/CBARR_August2013.pdf (dostęp: 29.01.2018).

https://www.opcw.org/news/article/libyas-remaining-chemical-weapon-precursorsarrive-safely-and-securely-at-german-facility-for-destruction/ (dostęp: 29.01.2018).

https://www.opcw.org/news/article/opcw-director-general-welcomes-un-securitycouncil-resolution-and-opcw-executive-council-decision-pledges-to-facilitateverifiable-destruction-of-libyas-remaining-chemical-weapons/ oraz https://www. opcw.org/fileadmin/OPCW/EC/M-52/en/ecm52dec01_e_.pdf (dostęp 29.01.2018).

http://www.royalnavy.mod.uk/news-and-latest-activity/news/2016/ august/31/160831-rfa-mounts-bay-supports-removal-of-potential-chemicalweapon-materials-from-libya (dostęp: 29.01.2018). 